\title{
Uji Aktivitas Antioksidan Ekstrak Etanol Daun Adas (Foeniculum Vulgare Mill) Dengan Metode DPPH Dan FRAP
}

\author{
Fridah Wahyu Safitri ${ }^{1}$, Ahwan Abdul' ${ }^{2}$, Fadilah Qonitah ${ }^{3}$ \\ ${ }^{1)}$ Mahasiswa Program Studi Farmasi, Universitas Sahid Surakarta, Indonesia \\ ${ }^{2,3)}$ Program Studi Farmasi, Universitas Sahid Surakarta, Indonesia \\ e-mail: ${ }^{1)}$ fridah6767@gmail.com ${ }^{2}$ ahone.far02@gmail.com ${ }^{3)}$ \\ fadilahqonitah12@gmail.com
}

\begin{abstract}
Abstrak
Antioksidan merupakan senyawa yang dapat meredam radikal bebas. Tanaman adas (Foeniculum Vulgare Mill) salah satu tanaman yang mengandung senyawa polifenol. Senyawa polifenol yang tinggi diketahui sebagai sumber antioksidan. Ekstraksi daun adas dilakukan dengan metode maserasi menggunakan pelarut etanol $96 \%$. Skrining fitokimia dengan metode KLT dilakukan secara kualitatif untuk mengetahui apakah ekstrak etanol daun adas mempunyai kandungan senyawa yang mampu memberikan aktivitas antioksidan menggunakan reaksi penyemprotan dengan DPPH. Aktivitas antioksidan ditentukan dengan metode DPPH (2,2 difenil-1-pikrilhidrazil) dan FRAP (Ferric Reducing Antioxidant Power) menggunakan instrumen spektrofotometri UV-Vis. DPPH merupakan uji aktivitas antioksidan berdasarkan transfer atom hidrogen, sedangkan FRAP berdasarkan kemampuan mereduksi ion ferri menjadi ferro. Hasil penelitian menunjukan bahwa ekstrak etanol daun adas pada metode DPPH dan FRAP mempunyai aktivitas antioksidan lemah $\left(\mathrm{IC}_{50}>150 \mu \mathrm{g} / \mathrm{mL}\right.$ ). Ditunjukan dari nilai $I_{50}$ DPPH sebesar $223,61 \mu \mathrm{g} / \mathrm{mL}$, dan FRAP sebesar $987,84 \mu \mathrm{g} / \mathrm{mL}$. Sedangkan Vitamin $\mathrm{C}$ sebagai pembanding menunjukan aktivitas antioksidan kuat $\left(\mathrm{IC}_{50}>150\right.$ $\mu \mathrm{g} / \mathrm{mL}$ ). Pada metode DPPH dihasilkan nilai IC 50 Vitamin C sebesar $3,20 \mu \mathrm{g} / \mathrm{mL}$ dan FRAP sebesar $31,1 \mu \mathrm{g} / \mathrm{mL}$.
\end{abstract}

Kata kunci: Antioksidan, Daun adas, DPPH, FRAP.

\section{Antioxidant Activity Test of Fennel Leaves Ethanol Extract (Foeniculum vulgare Mill) using DPPH and FRAP Methods}

\begin{abstract}
Antioxidants are compounds that can reduce free radicals. Fennel plant (Foeniculum vulgare Mill) is a plant that contains polyphenol compounds. High polyphenol compounds are known as a source of antioxidants. Extraction of fennel leaves was carried out by maceration method using $96 \%$ ethanol as a solvent. A preliminary test of antioxidant activity using the TLC method was carried out qualitatively to determine whether the ethanol extract of fennel leaves contained compounds capable of providing antioxidant activity using the spraying reaction with DPPH. Antioxidant activity was determined by DPPH (2,2 diphenyl-1-picrylhydrazyl) and FRAP (Ferric Reducing Antioxidant Power) methods using UV-Vis spectrophotometry. DPPH is an antioxidant activity test based on the transfer of hydrogen atoms, while FRAP is based on the ability to reduce ferric ions to ferrous. The results showed that the ethanol extract of fennel leaves in the DPPH and FRAP methods had weak antioxidant activity $\left(\mathrm{IC}_{50}>150 \mu \mathrm{g} / \mathrm{mL}\right)$. This is shown by the $\mathrm{IC}_{50} \mathrm{DPPH}$ value of $223.61 \mu \mathrm{g} / \mathrm{mL}$, and the FRAP value of $987.84 \mu \mathrm{g} / \mathrm{mL}$. Mean while, Ascorbic Acids as a comparison showed strong antioxidant activity $\left(\mathrm{IC}_{5} \mathrm{O}>150 \mu \mathrm{g} / \mathrm{mL}\right)$. In the DPPH
\end{abstract}


method, the $\mathrm{IC}_{50}$ Ascorbic acids value was $3.20 \mu \mathrm{g} / \mathrm{mL}$ and the FRAP was $31.1 \mu \mathrm{g} /$ $\mathrm{mL}$.

Keywords: Antioxidants, fennel leaves, DPPH, FRAP

\section{Pendahuluan}

Penyakit degeneratif merupakan penyakit nomor satu di Asia Tenggara. Berdasarkan data WHO tahun 2008, angka kematian di Asia Tenggara sekitar 14,5 juta, sekitar 55\% (7,9 juta) disebabkan oleh penyakit degeneratif (Tristantini et al., 2016). Beberapa penyakit degeneratif meliputi kanker, diabetes militus, aterosklerosis, penyakit kardiovaskuler, dan penyakit peradangan disebabkan salah satunya oleh proses stres oksidatif sebagai hasil dari ketidakseimbangan antara pembentukan dan netralisasi dari radikal bebas (Ghosh et al., 2013).

Radikal bebas merupakan atom atau gugus atom apa saja yang memiliki satu atau lebih elektron tak berpasangan sehingga bersifat sangat reaktif. Radikal bebas secara terus menerus terbentuk didalam tubuh, jika jumlahnya didalam tubuh sangat banyak dapat berpotensi menonaktifkan berbagai enzim, mengoksidasikan lemak dan mengganggu DNA tubuh sehingga terjadi mutasi sel yang merupakan awal timbulnya kanker (Handayani et al., 2016). Dalam hal ini radikal bebas dapat diatasi dengan penggunaan antioksidan (Tristantini et al., 2016). Dimana antioksidan atau biasa disebut senyawa penangkap radikal bebas merupakan zat yang dapat menetralkan radikal bebas, atau suatu bahan yang berfungsi mencegah sistem biologi tubuh dari efek yang merugikan yang timbul dari proses ataupun reaksi yang menyebabkan oksidasi yang berlebihan. Berbagai bukti ilmiah menunjukan bahwa senyawa antioksidan mengurangi resiko terhadap penyakit kronis seperti kanker dan jantung koroner (Prakash et al., 2001).

Berdasarkan sumbernya antioksidan dapat dibagi menjadi dua yaitu, antioksidan alami dan antioksidan sintetik. Antioksidan alami merupakan senyawa antioksidan yang terdapat secara alami dalam tubuh sebagai mekanisme pertahanan tubuh normal maupun berasal dari asupan luar tubuh. Sedangkan antioksidan sintetik merupakan senyawa yang disintesis secara kimia. Salah satu sumber senyawa antioksidan adalah tanaman dengan kandungan senyawa polifenol yang tinggi (Tristantini et al., 2016).

Salah satu tanaman yang mengandung polifenol adalah tanaman adas (Foeniculum Vulgare Mill). Tanaman adas banyak digunakan sebagai suplemen makanan kesehatan serta sebagai bumbu. Di Indonesia daun adas banyak dibudidayakan dan mempunyai banyak kegunaan mulai dari akar, daun, batang dan bijinya. Berdasarkan penelitian Ahwan (2019) menyatakan bahwa ekstrak etanol daun adas mengandung senyawa flavonoid, alkaloid, polifenol, saponin dan steroid (Abdul and Qonitah, 2019). Sedangkan pada penelitian yang dilakukan Badgujar et al (2014) tanaman adas mengandung minyak atsiri, flavonoid, fenolik, alkaloid dan steroid. Flavonoid diduga sangat bermanfaat dalam makanan, karena merupakan senyawa fenolik yang bersifat antioksidan kuat (Badgujar et al., 2014). Ini menunjukan beberapa efek biologis pada tubuh manusia, seperti antialergi, antibakteri, antifungi, antivirus, dan sebagai agen antikarsinogenik. Oleh karena pemanfaatannya yang beragam ini, kemudian flavonoid banyak dikembangkan menjadi obat-obatan (Payán-Gómez et al., 2010).

Penelitian yang dilakukan Saputra (2013) ekstrak etanol daun adas mempunyai aktivitas antioksidan dengan metode DPPH dengan $\mathrm{IC}_{50}$ sebesar 218,63 $\pm 5,8 \mu \mathrm{g} / \mathrm{mL}$. Berdasarkan penelitian tersebut dilakukan uji aktivitas ekstrak etanol daun adas dengan menggunakan dua metode yaitu, DPPH (2,2 difenil-1-pikrilhidrazi) dan FRAP (Ferric Reducing Antioxidant Power). Uji ini dilakukan karena penelitian sebelumnya hanya menguji aktivitas antioksidan ekstrak etanol daun adas dengan metode DPPH, 
sehingga belum pernah dilakukan dengan menggunakan metode FRAP. Berdasarkan hal tersebut uji aktivitas antioksidan ekstrak etanol daun adas dilakukan untuk mengetahui dan membandingkan seberapa besar aktivitas antioksidan yang dihasilkan dari metode DPPH dan FRAP.

\section{Metode Penelitian}

Penelitian ini merupakan penelitian bersifat eksperimental yang dilakukan dengan menentukan aktivitas antioksidan dari sampel ekstrak etanol daun adas dengan menggunakan dua metode DPPH dan FRAP. Cara kerja dalam penelitian ini sebagai berikut:

\section{Bahan dan Alat}

Bahan yang digunakan pada penelitian ini antara lain : simplisia daun adas yang berasal dari Cepogo Boyolali Jawa Tengah, etanol p.a (Emsure $\AA$ ), DPPH (Aldrich), $\mathrm{FeCl}_{3} 6 \mathrm{H}_{2} \mathrm{O}$ (Aldirch), Buffer asetat (Aldrich), $\mathrm{FeSO}_{4} 7 \mathrm{H}_{2} \mathrm{O}$ (Aldrich), $\mathrm{HCl}(E$ Merck), TPTZ (Aldrich), dan aquadest steril (Aldrich), vitamin $\mathrm{C}$ (Aldrich) dan $\mathrm{H}_{2} \mathrm{SO}_{4}(E$ Merck). $\mathrm{FeCl}_{3}$ (Aldrich) dan plat silika gel (E Merck).

Alat yang digunakan pada penelitian ini antara lain : alat-alat gelas (Schoot Duran), Spektrofotometer UV-Vis (Genesys 10S), kuvet, neraca analitik (ACIS), water bath (Memmert).

\section{Determinasi Tanaman}

Determinasi Tanaman dilakukan di Balai Besar Penelitian dan Pengembangan Tanaman Obat dan Obat Tradisional Tawangmangu.

\section{Penyiapan Sampel}

Sebanyak $1 \mathrm{~kg}$ daun adas kering yang sudah di sortasi direndam dengan etanol 96\% sebanyak 1 : 10 dalam maserator sambil diaduk-aduk tiap 12 jam lalu didiamkan selama 3 hari dan disaring. Maserat yang diperoleh kemudian diuapkan dengan rotary evaporator sampai kental. Kemudian diperoleh ekstrak kental.

\section{Skrining Fitokimia Golongan Senyawa}

Identifikasi dengan kromatografi lapis tipis (KLT) digunakan plat silika gel GF254 yang mampu berfluorosensi di bawah lampu UV pada panjang gelombang 254 $\mathrm{nm}$ dan $366 \mathrm{~nm}$. Ekstrak kasar tanaman adas dilarutkan dengan pelarutnya (dibuat 200 $\mathrm{mg}$ dalam $10 \mathrm{~mL}$ pelarutnya). Kemudian ditotolkan sebanyak $5 \mu \mathrm{L}$ pada jarak $1 \mathrm{~cm}$ dari tepi bawah plat silika gel GF254. Plat KLT dielusi dengan fase gerak $n$-Hexana, etil asetat, aceton (4:6:1). Noda-noda yang terbentuk pada plat silika gel GF254 kemudian diamati di bawah sinar UV pada panjang gelombang $254 \mathrm{~nm}$ dan $366 \mathrm{~nm}$. Kemudian disemprot dengan penampak noda (DPPH) dikeringkan, kemudian diamati masingmasing noda yang terbentuk (Maulana et al., 2019).

\section{Penentuan Aktivitas Antioksidan dengan Metode DPPH}

Penyiapan sampel. Ekstrak etanol daun adas ditimbang dengan 3 replikasi yang masing- masing $200 \mathrm{mg}$. Masing-masing ekstrak dilarutkan dalam etanol p.a sebanyak $10 \mathrm{~mL}$. Kemudian dihomogenkan.

Pembuatan larutan pereaksi DPPH 0,4 mM. Pereaksi DPPH 0,4 mM dibuat dengan melarutkan $15,7 \mathrm{mg}$ serbuk $\mathrm{DPPH}$ ke dalam $100 \mathrm{~mL}$ pelarut yang sesuai dengan pelarut sampel kemudian di homogenasi hingga larut sempurna (Murwanto and Santosa, 2012).

Penentuan panjang gelombang maksimum. Larutan stok DPPH 0,4 mM sebanyak $1,0 \mathrm{~mL}$ ditempatkan dalam labu takar $5,0 \mathrm{~mL}$ ditambah dengan etanol p.a 
sampai tanda, diukur absorbansinya pada panjang gelombang 450 - $545 \mathrm{~nm}$ terhadap blanko 5,0 mL etanol p.a, diplotkan harga absorbansi maksimum (Qonitah, 2018).

Penentuan waktu inkubasi sampel. Larutan stok DPPH 0,4 mM sebanyak 1,0 $\mathrm{mL}$ ditambahkan 50 mikro sampel kemudian ditambahkan etanol p.a sampai $5,0 \mathrm{~mL}$ kemudian divorteks selama 30 detik dan di ukur pada panjang gelombang maksimum, diplotkan dengan harga absorbansi dengan waktu. Pada penelitian ini, mengacu pada penelitian Molyneux (2004) yaitu waktu inkubasi 30 menit (Molyneux, 2004).

Penentuan aktivitas antiradikal. Beberapa seri konsentrasi sampel dalam rentang 100-1000 $\mathrm{gg} / \mathrm{mL}$ yang telah dibuat ditambah 1,0 $\mathrm{mL}$ DPPH 0,4 $\mathrm{mM}$ dan etanol p.a hingga $5,0 \mathrm{~mL}$. Campuran divortek selama 30 detik dan diinkubasi selama operating time (30 menit). Absorbansi diukur pada panjang gelombang maksimum terhadap blangko (etanol p.a). Dilakukan juga pengukuran absorbasi kontrol yang terdiri atas 1,0 mL DPPH dan etanol p.a hingga 5,0 mL pada waktu tertentu.

Analisis perhitungan $I C_{50}$. Dalam perhitungan DPPH besarnya aktivitas peredaman radikal menurut Sreenivasan et al (2007) dihitung dengan rumus:

$$
\text { (\%) perendaman }=\frac{(\text { A Kontrol }- \text { A Sampel })}{\text { A Kontrol }} \times 100 \%
$$

(Sreenivasan et al., 2007) $\mathrm{IC}_{50}$ adalah konsentrasi ekstrak daun adas yang menghasilkan penangkapan $50 \%$ senyawa radikal, yang dibandingkan dengan kontrol melalui suatu persamaan garis regresi linier antara kadar terhadap persen penangkap radikal (Haryoto et al., 2009).

\section{Penentuan Aktivitas Antioksidan dengan Metode FRAP}

Pembuatan Larutan:

Buffer Asetat. Buffer asetat dengan $\mathrm{pH} 3,6$ dibuat dari 0,775 gram natrium asetat trihidrat $\left(\mathrm{CH}_{3} \mathrm{COONa} .3 \mathrm{H}_{2} \mathrm{O}\right)$ yang ditambahkan dengan $4 \mathrm{~mL}$ asam asetat pekat dan dilarutkan dengan aquades hingga tepat $250 \mathrm{~mL}$ dalam labu takar (Samosir et al., 2012).

Larutan $10 \mathrm{mmol} / \mathrm{L}$ 2,4,6-tripyridil-striazine (TPTZ). Sebanyak $31 \mathrm{mg}$ TPTZ dilarutkan dalam $40 \mathrm{mmol} / \mathrm{L} \mathrm{HCl}$ hingga tepat $10 \mathrm{~mL}$. Larutan $40 \mathrm{mmol} / \mathrm{L} \mathrm{HCl}$ dibuat dengan melarutkan $380 \mu \mathrm{L} \mathrm{HCl}$ pekat dalam $100 \mathrm{~mL}$ aquades (Samosir et al., 2012).

Larutan $20 \mathrm{mmol} / \mathrm{L} \mathrm{FeCl}{ }_{3} 6 \mathrm{H}_{2} \mathrm{O}$. Sebanyak $32,44 \mathrm{mg} \mathrm{FeCl} 3.6 \mathrm{H}_{2} \mathrm{O}$ dilarutkan dengan buffer asetat dalam labu takar hingga tepat $10 \mathrm{~mL}$ (Samosir et al., 2012).

Reagen FRAP. Reagen FRAP dibuat dengan cara mencampurkan $25 \mathrm{~mL}$ buffer asetat, $2,5 \mathrm{~mL}$ larutan TPTZ dan 2,5 larutan $\mathrm{FeCl}_{3} \cdot 6 \mathrm{H}_{2} \mathrm{O}$, lalu ditambahkan aquades hingga tepat $100 \mathrm{~mL}$ dalam labu takar (Samosir et al., 2012).

Larutan Standar $\mathrm{FeSO}_{4} .7 \mathrm{H}_{2} \mathrm{O}$. Larutan stock 1000 ppm $\mathrm{FeSO}_{4} .7 \mathrm{H}_{2} \mathrm{O}$ dibuat dengan melarutkan $100 \mathrm{mg} \mathrm{FeSO} 4.7 \mathrm{H}_{2} \mathrm{O}$ dalam $100 \mathrm{~mL}$ aquades. Selanjutnya dibuat seri konsentrasi 100-1000 $\mu \mathrm{mol} / \mathrm{L}$ (Samosir et al., 2012).

Penentuan Aktivitas Antioksidan. Beberapa seri konsentrasi $100-1000 \mu \mathrm{g} / \mathrm{mL}$ yang telah dibuat ditambah $3 \mathrm{~mL}$ FRAP dan etanol pa hingga 5,0 mL. Campuran divortek 30 detik dan di inkubasi selama operating time (30 menit). lalu dibaca pada setiap panjang gelombang dalam kisaran 588 - 598 nm dengan menggunakan spektrofotometer visibel (Samosir et al., 2012).

Analisis perhitungan $I C_{50}$. Perhitungan FRAP diperoleh dari data absorbansi terhadap pengenceran serial Ferrous Sulfat $\left(\mathrm{FeSO}_{4} .7 \mathrm{H}_{2} \mathrm{O}\right)$ dan catat setara dengan $\mu \mathrm{M}$ $\mathrm{Fe}^{2+}$. Konsentrasi efektif $\mathrm{IC}_{50}$ dari nilai FRAP adalah konsentrasi sampel yang diperlukan untuk mengurangi 0,5 mol Fe ${ }^{3+}$ menjadi Fe ${ }^{2+}$ (Karim et al., 2014). 


\section{Analisis data}

Data yang diperoleh dari pengujian aktivitas antioksidan dilakukan dengan analisis statistik pada uji Independen T-test. Dalam penelitian ini uji Independen T-test digunakan untuk membandingkan apakah terdapat perbedaan signifikan aktivitas antioksidan pada ekstrak etanol daun adas dengan menggunakan metode DPPH dan FRAP.

\section{Hasil dan Pembahasan}

\section{Determinasi Tanaman}

Determinasi suatu tanaman dilakukan untuk mengetahui kebenaran identitas tanaman yang akan di uji. Hal ini bertujuan untuk memastikan bahwa tanaman yang digunakan adalah bener-benar tanaman yang di inginkan. Dengan demikian kesalahan dalam pengumpulan bahan yang akan di uji dapat di hindari. Tanaman adas (Foeniculum vulgare Mill) yang digunakan dalam penelitian ini, dideterminasi di Balai Besar Penelitian dan Pengembangan Tanaman Obat dan Obat Tradisional yang berada di Tawangmangu, Karanganyar Jawa Tengah. Adapun hasil Determinasi Tanaman menyatakan bahwa sampel yang digunakan merupakan tanaman spesies adas (Foeniculum vulgare Mill), dengan sinonim Anethum foeniculum officinale All yang merupakan famili Apiaceae.

\section{Ekstraksi Sampel dengan Metode Maserasi}

Proses ekstraksi daun adas dilakukan menggunakan metode maserasi. Metode maserasi merupakan cara ekstraksi yang sederhana yang dilakukan dengan cara merendam simplisia dalam pelarut hingga beberapa hari pada temperatur kamar yang terlindungi dari cahaya (Damayanti and Fitriana, 2012). Keuntungan dari metode ini adalah peralatan yang digunakan cukup sederhana.

Dalam penelitian ini simplisia daun adas direndam dalam etanol $96 \%$ dengan perbandingan 1:10 dalam maserator. Proses perendaman berlangsung selama 3 hari dalam tempat tertutup dan gelap, sambil di aduk tiap 12 jam di dengan tujuan agar proses ekstraksi berlangsung secara efektif (Damayanti and Fitriana, 2012). Setelah 3 hari proses maserasi dihentikan hingga diperoleh ekstrak cair yang kemudian dilanjutkan pada tahap penyaringan.

Tahap penyaringan dilakukan untuk memisahkan antara ampas daun adas dengan filtrat daun adas. Proses selanjutnya adalah penguapan dengan menggunakan rotary evaporator yang bertujuan untuk memisahkan ekstrak daun adas dengan pelarut. Setelah itu ekstrak yang telah menyusut akan diuapkan kembali dengan waterbath hingga diperoleh ekstrak kental. Pada bagian ampas daun adas yang telah dipisahkan, dilakukan remaserasi dengan menggunakan pelarut yang sama dengan jumlah yang sama pula menghasilkan ekstrak yang banyak.

Tabel 1. Hasil rendemen ekstrak etanol daun adas

\begin{tabular}{cccc}
\hline Simplisia & $\begin{array}{c}\text { Berat Serbuk } \\
(\mathbf{k g})\end{array}$ & $\begin{array}{c}\text { Berat Ekstrak } \\
\text { Kering }(\mathrm{kg})\end{array}$ & $\begin{array}{c}\% \text { rendemen } \\
(\% \mathrm{~b} / \mathrm{v})\end{array}$ \\
\hline \hline $\begin{array}{c}\text { Daun Adas } \\
\text { (Foeniculum Vulgare Mill) }\end{array}$ & 0,4629 & 0,0493 & 10,65 \\
\hline
\end{tabular}

Tabel 1. diperoleh hasil rendemen ekstrak daun adas sebesar 10,65\%. Semakin besar rendemen yang dihasilkan, maka semakin efisien perlakuan yang diterapkan. Nilai rendemen yang tinggi menunjukan banyaknya komponen bioaktif yang terkandung didalam ekstrak (Dewi et al., 2015). 


\section{Skrining Fitokima Golongan Senyawa}

Uji pendahuluan aktivitas antioksidan dengan KLT dilakukan secara kualitatif untuk mengetahui apakah ekstrak etanol daun adas mempunyai kandungan senyawa yang mampu memberikan aktivitas antioksidan menggunakan reaksi penyemprotan dengan DPPH. Kromatografi merupakan metode pemisahan berdasarkan perbedaan distribusi komponen-komponen dalam campuran fase diam dan fase gerak. Prinsip dari KLT dimana suatu analit bergerak melintasi lapisan fase diam dibawah pengaruh fase gerak yang bergerak melalui fase diam. Fase diam berupa padatan penyerap yang dihasilkan pada sebuah plat datar. Sedangkan fase gerak merupakan medium angkut yang terdiri dari satu atau lebih pelarut tertentu dan sebagai faktor yang menentukan gerakan komponen dalam campuran (Syahmani et al., 2017).

(A)

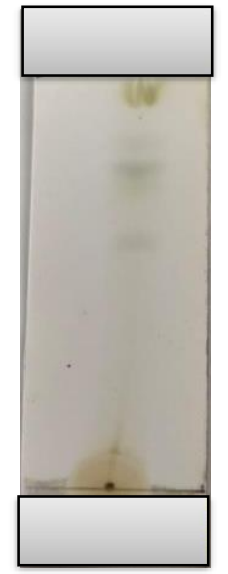

(B)

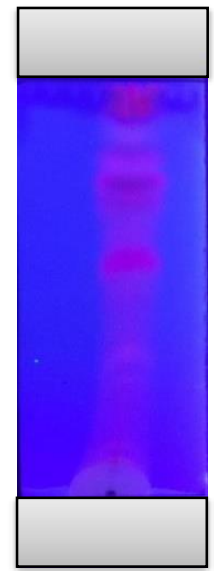

Gambar 1. Profil senyawa KLT. (A) Sebelum deteksi semprot dengan DPPH, (B) Sebelum deteksi semprot dengan DPPH pada UV $366 \mathrm{~nm}$.

Dalam penelitian ini digunakan fase diam silika Gel GF254 (bersifat polar) dengan jarak elusi $8 \mathrm{~cm}$, sedangkan fase gerak yang digunakan adalah $\mathrm{n}$ - Hexana (non polar), etil asetat (semi polar) dan Aceton (semi polar) dengan perbandingan 4:6:1. Berdasarkan penelitian Abdul (2019) menyatakan bahwa daun adas diketahui mengandung senyawa flavonoid sedangkan berdasarkan Badgujar (2014) daun adas mengandung fenolik. Dimana senyawa-senyawa tersebut cenderung bersifat semipolar dan polar, sehingga proses pemisahan dengan metode KLT menggunakan fase gerak tersebut dapat berjalan optimal ditunjukan dengan harga Rf.

Analisis kualitatif dengan metode KLT dilakukan untuk mendeteksi keberadaan senyawa yang dapat memberikan aktivitas antioksidan. Dalam analisis KLT dilakukan deteksi awal tanpa reaksi penyemprotan dengan pengamatan pada UV 254 dan 366 $\mathrm{nm}$. Hasil menunjukan terdapat beberapa profil kandungan senyawa yang berbedabeda yang terlihat pada UV 366. Hal ini memerlukan analisis lanjutan dengan pereaksi semprot. Deteksi dengan semprot dilakukan terhadap senyawa yang mengandung gugus hidroksi dengan menggunakan pereaksi DPPH (Hikmah, 2012). 
(C)

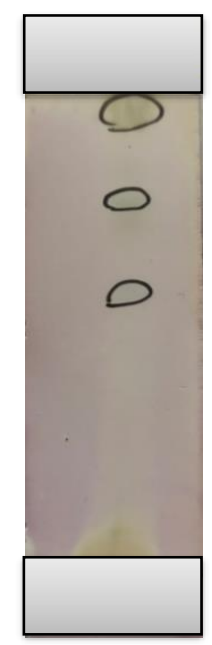

(D)

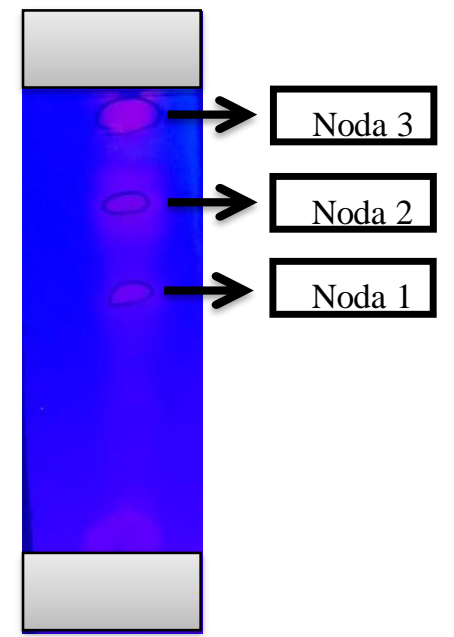

Gambar 2. Profil senyawa KLT. (C) Setelah deteksi semprot dengan DPPH, (D) Setelah deteksi semprot dengan DPPH pada UV $366 \mathrm{~nm}$.

Hasil menunjukan bahwa ketika plat KLT disemprotkan dengan DPPH 0,4 mM dalam etanol terjadi perubahan warna bercak menjadi warna hijau kekuningan, yang menunjukan adanya penurunan intensitas cahaya dari DPPH yang berarti terjadi aktivitas penangkapan radikal. Dalam hal ini profil kandungan senyawa sebelum disemprotkan DPPH terdiri dari beberapa profil senyawa, namun setelah deteksi semprot dengan DPPH 0,4 mM terbentuk 3 spot noda dengan warna hijau kekuningan yang menunjukan bahwa terdapat aktivitas antioksidan pada ekstrak etanol daun adas.

Hasil spot pada KLT setelah disemprot DPPH dihitung harga Rf untuk menunjukan kekuatan polaritas dari senyawa uji. Senyawa yang terelusi lebih cepat mempunyai harga $\mathrm{Rf}$ yang tinggi, cenderung memiliki sifat kepolaran yang rendah atau bersifat non polar. Sebaliknya jika nilai $\mathrm{Rf}$ rendah maka artinya senyawa yang terkandung dalam tanaman uji banyak mengandung senyawa polar. Senyawasenyawa yang terpisah terjadi karena perbedaan absorbsi fase diam oleh fase gerak. Dalam hal ini Afinitas analit terhadap fase diam dan fase gerak tergantung kedekatan polaritas analit terhadap fase diam dan fase gerak (like dissolve like) sehingga analit akan cenderung larut dalam fase polaritas yang sama (Wulandari L, 2011)

Hasil harga Rf yang didapat dalam penelitian ini, yaitu pada noda 1 sebesar 0,54 , pada noda 2 sebesar 0,74 dan pada noda 3 sebesar 0,88 . Pada nilai Rf tersebut senyawa ekstrak etanol daun adas diketahui mampu memberikan aktivitas antioksidan. (Dewi et al., 2015) menyatakan rentang nilai Rf memenuhi persyaratan KLT adalah $0,2-0,8$. Berdasarkan hasil penelitian diatas diketeahui bahwa nilai Rf pada noda 1, 2 dan 3 memenuhi persyaratan KLT dan artinya senyawa uji cenderung bersifat semi polar dan diketahui memiliki senyawa yang mampu menangkap radikal bebas ditunjukan melalui deteksi semprot dengan pereaksi DPPH.

\section{Uji Aktivitas Antioksidan}

Uji Aktivitas Antioksidan Dengan Metode DPPH Secara Spektrofotometri UV-Vis

Aktivitas antioksidan pada ekstrak etanol daun adas di ukur dengan menggunakan metode DPPH. Radikal DPPH merupakan radikal stabil yang menyerap cahaya pada $\lambda 517 \mathrm{~nm}$ dengan warna ungu. Reaksi dengan donor hidrogen menyebabkan DPPH radikal menjadi DPPH berwarna kuning sehingga menurunkan intensitas serapan warna ungu pada $\lambda 517 \mathrm{~nm}$ (Hikmah, 2012). Metode DPPH merupakan metode yang sangat sederhana, cepat dan mudah dilakukan. Prinsip kerja 
dari metode DPPH adalah berdasarkan kemampuan DPPH untuk menerima atom hidrogen yang di donorkan oleh antioksidan (Haryoto et al., 2009).

Dalam penelitian ini DPPH $0,4 \mathrm{mM}$ sebanyak $1 \mathrm{~mL}$ dalam etanol $5 \mathrm{~mL}$ pada labu ukur ditentukan $\lambda$ maks dan Operating time (OT). DPPH umumnya mudah larut dalam pelarut polar, seperti air, metanol dan etanol. Pemilihan etanol dalam penelitian ini karena DPPH lebih baik kelarutannya pada etanol (Haryoto et al., 2009). Berdasarkan penelitian Marinova et al (2011) menyatakan bahwa etanol lebih presisi dan dapat menghasilkan persen inhibisi lebih tinggi dari pada metanol (Marinova and Batchvarov, 2011). Penentuan $\lambda$ maks bertujuan untuk mengetahui panjang gelombang maksimum larutan DPPH 0,4 $\mathrm{mM}$ yang dapat memberikan hasil pengukuran maksimal. Sedangkan OT merupakan waktu optimum dalam menghasilkan absorbansi yang stabil saat senyawa bereaksi dengan DPPH (Saputra, 2013). Dalam penelitian ini dihasilkan $\lambda$ maks $517 \mathrm{~nm}$ dengan OT selama 30 menit hal ini sesuai dengan penelitian Molyneux (2004) yang menyatakan waktu inkubasi 30 menit (Molyneux, 2004).

Aktivitas antioksidan dalam penelitian ini dinyatakan dalam nilai $I_{50}$. Nilai $I_{50}$ merupakan besarnya konsentrasi senyawa uji yang dapat meredam $50 \%$ radikal bebas. Semakin kecil nilai $I_{50}$ maka aktivitas antiradikal semakin tinggi. Nilai $I_{50}$ diperoleh dari persamaan regresi linier antara persen penangkap radikal sebagai $Y$ dan konsentrasi ekstrak etanol daun adas sebagai X (Yuslianti, 2018).

Tabel 2. Hasil Aktivasi Antioksidan dengan Metode DPPH

\begin{tabular}{|c|c|c|c|c|c|c|}
\hline \multirow[t]{2}{*}{ Sampel } & \multicolumn{3}{|c|}{ IC $50(\mu \mathrm{g} / \mathrm{mL})$} & \multirow{2}{*}{$\begin{array}{c}\text { Rata-rata } \\
\text { IC50 }(\mu \mathrm{g} / \mathrm{mL})\end{array}$} & \multirow{2}{*}{$\begin{array}{c}\text { Kolmogorov- } \\
\text { Smirnov }\end{array}$} & \multirow[t]{2}{*}{ T-Test } \\
\hline & I & II & II & & & \\
\hline $\begin{array}{c}\text { Ekstrak Etanol } \\
\text { daun Adas }\end{array}$ & 224.17 & 224.33 & 222.34 & $223.61 \pm 1.10$ & 0.765 & $0.000^{*}$ \\
\hline Vitamin C & 3.03 & 3.36 & 3.23 & $3.20 \pm 0.16$ & 0.142 & \\
\hline
\end{tabular}

Keterangan : Data terdistribusi normal $(p>0,05):{ }^{*}$ Terdapat perbedaan signifikan $(p<0,05)$.

Berdasarkan hasil penelitian pada Tabel 2. menunjukan bahwa uji aktivitas antioksidan ekstrak etanol daun adas dengan metode DPPH menghasilkan nilai ratarata $\mathrm{IC}_{50}$ sebesar $223,61 \pm 1,10 \mu \mathrm{g} / \mathrm{mL}$, yang termasuk aktivitas antioksidan tergolong lemah. Senyawa antioksidan dapat dikategorikan sangat kuat jika memiliki nilai $I_{50}$ kurang dari $50 \mu \mathrm{g} / \mathrm{mL}$, antioksidan kuat jika memiliki nilai $I_{50}$ antara $50-100 \mu \mathrm{g} / \mathrm{mL}$, antioksidan sedang memiliki $\mathrm{IC}_{50}$ antara $101-150 \mu \mathrm{g} / \mathrm{mL}$, antioksidan lemah memiliki $\mathrm{IC}_{50}$ lebih dari $150 \mu \mathrm{g} / \mathrm{mL}$ (Kusmardiyani et al., 2016).

Vitamin $\mathrm{C}$ yang telah diketahui memiliki aktivitas antioksidan digunakan sebagai pembanding. Hasil pengukuran menunjukan bahwa Vitamin $\mathrm{C}$ memiliki nilai $\mathrm{IC}_{50}$ sebesar 3,20 $\pm 0,16 \mu \mathrm{g} / \mathrm{mL}$. Hasil tersebut menunjukan bahwa semakin kecil nilai $I_{50}$ maka semakin besar kapasitas antioksidannya. Hal ini berarti bahwa aktivitas antioksidan Vitamin C lebih besar dari pada aktivitas antioksidan sampel ekstrak etanol daun adas. Kemudian kedua hasil data diatas diuji normalitasnya untuk menentukan data yang terkumpul terdistribusi normal atau tidak.

Berdasarkan hasil uji normalitas dengan menggunakan metode KolmogrovSmirnov, menunjukan nilai $\mathrm{IC}_{50}$ ekstrak etanol daun adas dan Vitamin $\mathrm{C}$ signifikan $(p>0,05)$ yang artinya data terdistribusi normal sehingga dapat dilanjutkan menggunakan uji statistik T-Test. Uji statistik T-test merupakan salah satu uji untuk mengetahui perbedaan antara dua sampel yang berbeda. Interpretasi data dapat dilihat dari nilai signifikan $(p<0,05)$ berarti ada perbedaan yang signifikan antara dua variabel yang berbeda dan sebaliknya (Sani, 2016). Uji ini dilakukan untuk mengetahui ada atau tidaknya perbedaan signifikan dari nilai $\mathrm{IC}_{50}$ ekstrak adas dan Vitamin $\mathrm{C}$. Berdasarkan hasil uji $T$-test menunjukan bahwa aktivitas antioksidan Vitamin $\mathrm{C}$ dan ekstrak etanol daun adas dengan metode DPPH berbeda secara signifikan $(p<0,05)$.

Pharmed Vol. 3, No. 2, Agustus 2020: $43-54$ 
Penelitian lain melaporkan bahwa aktivitas antioksidan fraksi etil asetat pada daun adas dengan metode DPPH menghasilkan nilai $\mathrm{IC}_{50}$ sebesar $218,63 \pm 5,8 \mu \mathrm{g} / \mathrm{mL}$ yang artinya intensitas antioksidan yang dihasilkan masuk dalam kategori lemah (Saputra, 2013).

\section{Uji Aktivitas Antioksidan dengan Metode FRAP}

Penelitian ini digunakan $\mathrm{FeSO}_{4} .7 \mathrm{H}_{2} \mathrm{O}$ sebagai standar baku untuk menentukan kurva baku yang berperan dalam perhitungan kapasitas antioksidan dalam sampel. Hasil regresi dari konsentrasi $(x)$ dengan nilai absorbansi $(y)$ standar $\mathrm{FeSO}_{4} .7 \mathrm{H}_{2} \mathrm{O}$ menghasilkan persamaan $Y=0,0014 x+0,5437$ dengan nilai $R^{2} 0,9898$, sehingga data absorbansi sampel dimasukan ke persamaan tersebut untuk mengetahui kapasitas antioksidan. Untuk menentukan nilai $I_{50}$ berdasarkan Karim et al (2014) menyatakan bahwa konsentrasi efektif pada $50 \%\left(\mathrm{IC}_{50}\right)$ dari nilai FRAP adalah konsentrasi sampel yang diperlukan untuk mengurangi $0,5 \mathrm{~mol}(500 \mu \mathrm{M}) \mathrm{Fe}^{3+}$ menjadi $\mu \mathrm{M} \mathrm{Fe}{ }^{2+}$.

Tabel 3. Hasil Aktivasi Antioksidan dengan Metode FRAP

\begin{tabular}{|c|c|c|c|c|c|c|}
\hline \multirow[t]{2}{*}{ Sampel } & \multicolumn{3}{|c|}{ IC $50(\mu \mathrm{g} / \mathrm{mL})$} & \multirow{2}{*}{$\begin{array}{c}\text { Rata-rata } \\
\text { IC50 }(\mu \mathrm{g} / \mathrm{mL})\end{array}$} & \multirow{2}{*}{$\begin{array}{c}\text { Kolmogorov- } \\
\text { Smirnov }\end{array}$} & \multirow[t]{2}{*}{ T-Test } \\
\hline & I & II & II & & & \\
\hline $\begin{array}{l}\text { Ekstrak Etanol } \\
\text { daun Adas }\end{array}$ & 988.99 & 988.82 & 985.71 & $987.84 \pm 1.84$ & 0.088 & $0.000^{*}$ \\
\hline Vitamin C & 31.49 & 31.24 & 30.57 & $31.1 \pm 0.47$ & 0.503 & \\
\hline
\end{tabular}

Keterangan : Data terdistribusi normal $(p>0,05):{ }^{*}$ Terdapat perbedaan signifikan $(p<0$

Berdasarkan hasil penelitian pada Tabel 3. menunjukan bahwa uji aktivitas antioksidan pada ekstrak etanol daun adas dengan metode FRAP menghasilkan nilai $\mathrm{IC}_{50}$ sebesar $987,84 \pm 1,84 \mu \mathrm{g} / \mathrm{mL}$ yang termasuk aktivitas antioksidan kategori lemah. Vitamin $\mathrm{C}$ yang telah diketahui memiliki aktivitas antioksidan digunakan sebagai pembanding. Hasil pengukuran menunjukan bahwa Vitamin $\mathrm{C}$ pada uji FRAP memiliki nilai $I_{50}$ sebesar $31,1 \pm 0,47 \mu \mathrm{g} / \mathrm{mL}$. Hasil tersebut menunjukan bahwa aktivitas antioksidan Vitamin $\mathrm{C}$ termasuk dalam intensitas antioksidan kuat, yang artinya aktivitas antioksidan Vitamin $\mathrm{C}$ lebih besar dari pada aktivitas antioksidan sampel ekstrak etanol daun adas. Kemudian kedua hasil data diatas diuji normalitasnya untuk menentukan data yang terkumpul terdistribusi normal atau tidak. Berdasarkan hasil uji normalitas dengan menggunakan metode Kolmogrov-Smirnov, menunjukan nilai $\mathrm{IC}_{50}$ ekstrak etanol daun adas dan Vitamin $C$ signifikan $(p>0,05)$ yang artinya data terdistribusi normal sehingga dapat dilanjutkan menggunakan uji statistik T-Test. Berdasarkan hasil uji T-test pada metode FRAP menunjukan bahwa aktivitas antioksidan Vitamin $\mathrm{C}$ dan ekstrak etanol daun adas berbeda secara signifikan $(p<0,05)$.

\section{Perbandingan Uji Aktivitas Antioksidan Ekstrak Etanol Daun Adas dengan Metode DPPH dan FRAP}

Aktivitas antioksidan yang dihasilkan dengan metode DPPH dan FRAP dibandingkan, untuk mengetahui adakah perbedaan nilai $\mathrm{IC}_{50}$ yang dihasilkan dari kedua metode. Adapun hasil dari kedua metode dapat dilihat pada tabel berikut :

Tabel 4. Hasil Aktivasi Antioksidan dengan Metode DPPH dan FRAP

\begin{tabular}{ccccccc}
\hline Sampel & \multicolumn{3}{c}{ IC $5 \mathbf{5 0}(\boldsymbol{\mu g} / \mathbf{m L})$} & $\begin{array}{c}\text { Rata-rata } \\
\text { IC50 }(\boldsymbol{\mu g} / \mathbf{m L})\end{array}$ & $\begin{array}{c}\text { Kolmogorov- } \\
\text { Smirnov }\end{array}$ & T-Test \\
\cline { 2 - 6 } & I & II & II & $223.61 \pm 1.10$ & 0.765 & \multirow{2}{*}{$0.000^{*}$} \\
\hline DPPH & 224.17 & 224.33 & 222.34 & 223.85 & \\
\hline FRAP & 988.99 & 988.82 & 985.71 & $987.84 \pm 1.84$ & 0.088 & \\
\hline
\end{tabular}

Keterangan : Data terdistribusi normal $(p>0,05):{ }^{*}$ Terdapat perbedaan signifikan $(p<0$

Berdasarkan Tabel 4. menunjukan bahwa nilai $I_{50}$ pada FRAP $(987,84 \mu \mathrm{g} / \mathrm{mL}$ $\pm 1,84)$ jauh lebih besar dibandingkan metode DPPH $(223,61 \mu \mathrm{g} / \mathrm{mL} \pm 1,10)$. Hal ini

Uji Aktivitas Antioksidan Ekstrak Etanol Daun Adas (Feoniculum Vulgare Mill) Dengan Metode DPPH dan FRAP .. (Frida Wahyu Safitri) 
dikarenakan uji DPPH mengukur kemampuan senyawa antioksidan pada sampel dalam melakukan Scavenging terhadap senyawa radikal. Sementara uji FRAP mengukur kemampuan senyawa antioksidan pada sampel dengan mereduksi ion ferri menjadi ferro(Pratiwi and Giriwono, 2017). Meskipun kedua metode ini termasuk metode dengan transfer elektron namun mekanisme pada uji DPPH dapat terjadi dengan mekanisme transfer atom hidrogen, sedangkan FRAP hanya berdasarkan transfer elektron saja. Selain itu FRAP tidak dapat mendeteksi senyawa yang memiliki mekanisme aksi peredaman radikal ( $H$ transfer).

Reaksi pada $\mathrm{pH}$ rendah mengurangi potensi ionisasi yang mendorong transfer elektron dan meningkatkan potensi redoks. Sehingga mekanisme pada FRAP hanya berdasarkan pada transfer elektron bukan merupakan gabungan SET (single electron transfer) dan HAT (hydrogen atom transfer). Berdasarkan pernyataan tersebut sangat mungkin terjadi adanya perbedaan kapasitas antioksidan hasil pengukuran DPPH dan FRAP pada sempel karena tidak semua komponen antioksidan pada sampel memiliki kemampuan sebagai agen pereduksi dan kemampuan scavenging radikal sekaligus (Wang et al., 2012). Selain itu berdasarkan penelitian Fidrianny et al (2014) menjelaskan hal serupa bahwa metode DPPH dan FRAP memiliki mekanisme reaksi yang berbeda, dimana DPPH memiliki mekanisme berupa transfer elektron dan FRAP memiliki mekanisme reduksi (Fidrianny et al., 2014).

Uji T-Test dilakukan terhadap nilai $\mathrm{IC}_{50}$ dari metode DPPH dan FRAP. Hal ini dilakukan untuk mengetahui apakah terdapat perbedaan aktivitas antioksidan yang signifikan dari kedua metode tersebut. Berdasarkan hasil uji T-test menunjukan bahwa $I_{50}$ pada metode FRAP dan DPPH berbeda secara signifikan $(p<0,05)$. Hasil tersebut sesuai dengan penelitian Kusmardiyani et al (2016) yang menunjukan bahwa aktivitas antioksidan ekstrak kalakai dengan metode DPPH dan FRAP terdapat perbedaan signifikan $(p<0,05)$ (Kusmardiyani et al., 2016). Penelitian diatas juga menjelaskan bahwa metode yang berbeda dalam evaluasi aktivitas antioksidan memungkinkan hasil yang berbeda pula.

Aktivitas antioksidan ekstrak etanol daun adas yang dihasilkan dari metode DPPH dan FRAP tergolong lemah $\left(\mathrm{IC}_{50}>150 \mu \mathrm{g} / \mathrm{mL}\right)$. Hal ini dikarenakan kadar senyawa yang mampu memberikan aktivitas antioksidan pada sampel memiliki kadar dalam jumlah yang rendah. Salah satunya adalah senyawa fenolik, berdasarkan penelitian (Saputra, 2013) tentang penetapan kadar fenolik total dan uji aktivitas antioksidan fraksi etil asetat ekstrak etanol daun adas menggunakan metode DPPH menyatakan bahwa rata-rata kandungan fenolik total fraksi etil asetat daun adas sebesar 4,88 $\mathrm{mg}$ GAE/g dengan nilai $\mathrm{IC}_{50}$ sebesar 218,63 $\mu \mathrm{g} / \mathrm{mL}$. Sedangkan berdasarkan penelitian Ahwan (2020) menyatakan bahwa kadar fenolik total daun adas sebesar $0,2106 \%(2,106 \mu \mathrm{g}$ GAE/g) (Abdul et al., 2020). Sedangkan berdasarkan penelitian Melannisa et al (2011) tentang uji aktivitas penangkap radikal bebas dan penetapan kadar fenolik total dengan sampel salah satunya ekstrak etanol kunyit, menyatakan bahwa kadar fenolik total (GAE) ekstrak etanol rimpang kunyit sebesar $179,71 \mathrm{mg} / \mathrm{g}$ dengan nilai $\mathrm{IC}_{50}$ sebesar $29,64 \mu \mathrm{g} / \mathrm{mL}$, sehingga aktivitas antioksidan yang dihasilkan tergolong sangat kuat $(<50 \mu \mathrm{g} / \mathrm{mL})$ (Melannisa et al., 2011). Berdasarkan hasil tersebut dapat diketahui bahwa senyawa fenolik berpengaruh terhadap aktivitas antioksidan dari sampel. Semakin besar kadar fenolik pada sampel maka memungkinkan pula besarnya potensi sampel sebagai antioksidan alami. Tristantini et al (2016) menyatakan bahwa salah satu sumber senyawa antioksidan adalah tanaman dengan kandungan senyawa polifenol yang tinggi. Senyawa polifenol salah satunya adalah fenolik (Tristantini et al., 2016).

\section{Kesimpulan}

Uji aktivitas antioksidan pada ekstrak etanol daun adas menghasilkan IC50 sebesar $223,61 \mu \mathrm{g} / \mathrm{mL} \pm 1,10$ dengan metode $\mathrm{DPPH}$, dan IC50 sebesar $987,84 \mu \mathrm{g} / \mathrm{mL} \pm 1,84$

Pharmed Vol. 3, No. 2, Agustus 2020: 43 - 54 
dengan metode FRAP. Sehingga dapat disimpulkan aktivitas antioksidan yang dihasilkan dari kedua metode masuk dalam kategori lemah. Vitamin $\mathrm{C}$ sebagai pembanding menghasilkan IC50 sebesar $3,20 \mu \mathrm{g} / \mathrm{mL} \pm 0,16$ dengan metode DPPH dan IC50 sebesar $31,1 \mu \mathrm{g} / \mathrm{mL} \pm 0,47$ dengan metode FRAP. Sehingga dapat disimpulkan aktivitas antioksidan pada vitamin $C$ masuk dalam kategori kuat. Berdasarkan hasil uji statistik T-Test diketahui terdapat perbedaan secara signifikan dari kedua metode $(p<0,05)$, sehingga dapat disimpulkan terdapat perbedaan aktivitas antioksidan dari metode DPPH dan FRAP.

\section{Daftar Pustaka}

Abdul, A., Qonitah, F., 2019. Pengaruh Pemberian Ekstrak Etanol Daun Adas terhadap Kadar Hormon Prolaktin pada Tikus Betina Post Partum. J. Farmasetis 8, 39-44.

Abdul, A., Safitri, F.W., Purbowati, R., 2020. Efek Pemberian Ekstrak Etanol Buah Adas (Foenicullum vulgare Mill.) terhadap Kadar Hormon Prolaktin Tikus Putih Betina Post Partum. Pharmacon J. Farm. Indones. 17, 1-8.

Badgujar, S.B., Patel, V. V., Bandivdekar, A.H., 2014. Foeniculum vulgare Mill: A review of its botany, phytochemistry, pharmacology, contemporary application, and toxicology. Biomed Res. Int. 2014, 1-32. https://doi.org/10.1155/2014/842674

Damayanti, A., Fitriana, E.A., 2012. Pemungutan minyak atsiri mawar (rose oil) dengan metode maserasi. J. Bahan Alam Terbarukan 1.

Dewi, T.M., Herawati, D., Hamdani, S., 2015. Analisis Kualitatif Residu Antibiotika Tetrasiklin pada Madu, in: Bandung, U.I. (Ed.), . Universitas Islam Bandung, Bandung.

Fidrianny, I., Harnovi, M., Insanu, M., 2014. Evaluation of antioxidant activities from various extracts of sweet orange peels using DPPH, FRAP assays and correlation with phenolic, flavonoid, carotenoid content. Asian J. Pharm. Clin. Res 7, 186190.

Ghosh, S., Derle, A., Ahire, M., More, P., Jagtap, S., Phadatare, S.D., Patil, A.B., Jabgunde, A.M., Sharma, G.K., Shinde, V.S., 2013. Phytochemical analysis and free radical scavenging activity of medicinal plants Gnidia glauca and Dioscorea bulbifera. PLoS One 8, e82529.

Handayani, V., Ahmad, A.R., Sudir, M., 2016. Uji aktivitas antioksidan ekstrak metanol bunga dan daun patikala (Etlingera elatior (Jack) RM Sm) menggunakan metode DPPH. Pharm. Sci. Res. 1, 86-93.

Haryoto, Suhendi, A., Ahwan, 2009. IDENTIFIKASI DAN AKTIVITAS ANTIOKSIDAN FRAKSI NON POLAR EKSTRAK ETANOL DAUN SRIKAYA (Annona squamosa. L) DENGAN METODE DPPH.

Hikmah, F.D., 2012. Pengaruh Partisi Bertingkat Cair-Cair Ekstrak Etanol Rimpang Jahe (Zingiber Officinale Rosc.) Terhadap Profil Kandungan Senyawa Kimia Dan Aktivitas Antiradikalnya.

Karim, A.A., Azlan, A., Ismail, A., Hashim, P., Abd Gani, S.S., Zainudin, B.H., Abdullah, N.A., 2014. Phenolic composition, antioxidant, anti-wrinkles and tyrosinase inhibitory activities of cocoa pod extract. BMC Complement. Altern. Med. 14, 381.

Kusmardiyani, S., Novita, G., Fidrianny, I., 2016. Antioxidant Activities from various extracts of different parts of Kelakai (Stenochlaena palustris) grown in Central Kalimantan-Indonesia. Asian J Pharm Clin Res 9, 215-219.

Marinova, G., Batchvarov, V., 2011. Evaluation of the methods for determination of the free radical scavenging activity by DPPH. Bulg. J. Agric. Sci. 17, 11-24. 
Maulana, T.I., Falah, S., Andrianto, D., 2019. Total phenolic content, total flavonoid content, and antioxidant activity of water and ethanol extract from Surian (Toona sinensis) leaves, in: IOP Conference Series: Earth and Environmental Science. IOP Publishing, p. 12021.

Melannisa, R., Da'i, M., Rahmi, R.T., 2011. Uji Aktivitas Penangkap Radikal Bebas Dan Penetapan Kadar Fenolik Total Ekstrak Etanol Tiga Rimpang Genus Curcuma Dan Rimpang Temu Kunci (Boesenbergia pandurata).

Molyneux, P., 2004. The use of the stable free radical diphenylpicrylhydrazyl (DPPH) for estimating antioxidant activity. Songklanakarin J. sci. technol 26, 211-219.

Murwanto, P.E., Santosa, D., 2012. Antioxidant Activity Analysis Of Cynara Scolimus L., Artemisia China L., Borreria Repensdc., polygala Paniculata L. From Taman Nasional Gunung Merapi Using Dpph (2, 2-difenil-1-pikrilhidrazil) Radical Scavenging Analysis. Maj. Obat Tradis. (Traditional Med. Journal) 17, 53-60.

Payán-Gómez, S.A., Flores-Holguín, N., Pérez-Hernández, A., Piñón-Miramontes, M., Glossman-Mitnik, D., 2010. Computational molecular characterization of the flavonoid rutin. Chem. Cent. J. 4, 12.

Prakash, A., Rigelhof, F., Miller, E., 2001. Medallion laboratories analytical progress: Antioxidant activity. J. DeVries, PhD (ed), Medallion Lab. 19, 1-6.

Pratiwi, G., Giriwono, P.E., 2017. Performance Kapasitas Antioksidan Teh Kulit Manggis, Teh Hitam, Teh Hijau Dan Teh Rosela. Institut Pertanian Bogor.

Qonitah, F., 2018. AKTIVITAS ANTIOKSIDAN DAN KANDUNGAN FENOLIK TOTAL DARI ISOLAT POLAR FRAKSI HEKSANA EKSTRAK ETANOL DAUN SIRIH (PIPER BETLE L.). J. Farmasetis 7, 42-46.

Samosir, A.P., Runtuwene, M.R.J., Citraningtyas, G., 2012. UJI AKTIVITAS ANTIOKSIDAN DAN TOTAL FLAVONOID PADA EKTRAK ETANOL PINANG YAKI (Areca vestiaria). Pharmacon 1.

Sani, F., 2016. Metodologi penelitian farmasi komunitas dan eksperimental. Yogyakarta Deep.

Saputra, B.A., 2013. Penetapan Kadar Fenolik Total Dan Uji Aktivitas Antioksidan Fraksi Etil Asetat Ekstrak Etanol Daun Adas (Foeniculum vulgare Mill) Menggunakan Metode DPPH. Skripisi. Universitas Sanata Dharma Yogyakarta.

Sreenivasan, S., Ibrahim, D., MOHD KASSIM, M.J.N., 2007. Free radical Scavenging Activity and Total Phenolic Compounds of Gracilaria changii. Int. J. Nat. Eng. Sci. 1.

Syahmani, S., Leny, L., Iriani, R., Elfa, N., 2017. PENGGUNAAN KITIN SEBAGAI ALTERNATIF FASE DIAM KROMATOGRAFI LAPIS TIPIS DALAM PRAKTIKUM KIMIA ORGANIK. Vidya Karya 32.

Tristantini, D., Ismawati, A., Pradana, B.T., Jonathan, J.G., 2016. Pengujian aktivitas antioksidan menggunakan metode DPPH pada daun tanjung (Mimusops elengi L), in: Seminar Nasional Teknik Kimia Kejuangan. p. 1.

Wang, J.J., Shi, Q.H., Zhang, W., Sanderson, B.J.S., 2012. Anti-skin cancer properties of phenolic-rich extract from the pericarp of mangosteen (Garcinia mangostana Linn.). Food Chem. Toxicol. 50, 3004-3013.

Wulandari L, 2011. Jember: PT, Kroatografi Lapis Tipis. Taman Kampus Presindo.

Yuslianti, E.R., 2018. Pengantar Radikal Bebas dan Antioksidan. Deepublish. 